\title{
DOSTOJNOŚĆ I CODZIENNOŚĆ AKADEMICKIEGO ŻYCIA - WPROWADZENIE DO WIODĄCEJ TEMATYKI TOMU
}

Na niejednym postronnym obserwatorze spore wrażenie mogą robić już same mury wyższych uczelni, a im mają dłuższą historię, tym wydają się bardziej dostojne. Ich wnętrza zdają się promieniować nie mniejszym, a czasami nawet jeszcze większym dostojeństwem w tych uczelniach, w których na eksponowanych miejscach znajduje się długa galeria portretów ich akademickich wielkości - jeśli nawet nie najbardziej zasłużonych w badaniach naukowych, to przynajmniej w pełnieniu uczelnianych funkcji. W końcu tytuł Magnificencji (łac. wspaniały) nobilituje, i to nie tylko dlatego, że przez jakiś czas nosi się rektorskie togi, łańcuchy, berła i pierścienie. Rzecz jasna, noszone są on przy okazji szczególnie ważnych uczelnianych wydarzeń, takich jak inauguracja roku akademickiego czy uroczyste nadanie uczonym tytułu honoris causa. Ci, którzy uczestniczyli w takich uroczystościach, mogli się naocznie przekonać nie tylko o tym, jak ważne jest kultywowanie tradycji w życiu akademickim, ale też jaki stosunek mają do niego wyróżnieni uczeni. Oczywiście stosunek ten był i jest rozmaity, z reguły bowiem tytuły otrzymują uczeni o wyrazistych osobowościach, potrafiący to pokazać m.in. w tych mowach, które zwyczajowo wygłaszają na takich uroczystościach.

Jedną z takich mów wygłosił w 1932 r. w auli Uniwersytetu Lwowskiego prof. Kazimierz Twardowski z okazji nadania mu przez Uniwersytet Poznański „godności honorowej Doktora Filozofii h.c. za zasługi naukowe”" . Zasługi

${ }_{1}$ Zob. http://www.ken.pan.pl/images/stories/pliki/pdf/twardowski2.pdf (dostęp: 15.12.2021). 
te związane były z jego osiągnięciami zarówno jako filozofa, jak i organizatora ówczesnego życia filozoficznego we Lwowie i w Warszawie (uznawany jest za założyciela filozoficznej szkoły lwowsko-warszawskiej, zob. Woleński, 1985). W tym wystąpieniu - zatytułowanym $O$ dostojeństwie Uniwersytetu - mówił o „głębokim wzruszeniu i splocie najżywszych uczuć napełniających jego duszę", a także, a nawet przede wszystkim, o tym dostojeństwie uniwersytetu, które „płynie nie tylko z sędziwego wieku i chlubnych tradycji uczelni, noszących tę nazwę, ma ono swe źródło w samej nazwie Uniwersytetu, która się z biegiem czasu ustaliła i która wyznacza mu funkcję, jaką on ma pełnić w życiu zbiorowym współczesnej ludzkości i rozlicznych jej odłamów narodowych. Według tej idei zadaniem Uniwersytetu jest zdobywanie prawd i prawdopodobieństw naukowych oraz krzewienie umiejętności ich dochodzenia. Rdzeniem i jądrem pracy uniwersyteckiej jest tedy twórczość naukowa, zarówno pod względem merytorycznym, jak pod względem metodycznym”. Podkreślił przy tym, że „możność spełnienia właściwych Uniwersytetowi zadań jest uwarunkowana bezwzględną duchową niezależnością. Duchową - bo materialnie Uniwersytet, o ile stoi o własnych siłach, będzie zawsze zależny od tego czynnika, który mu daje finansowe podstawy istnienia i wyposaża go w środki do pracy. Ale ci, co Uniwersytety fundują i utrzymują, dowiedliby zupełnego niezrozumienia istoty Uniwersytetu, gdyby chcieli w czymkolwiek krępować jego pracę, z góry zastrzegać się przeciw pewnym jej wynikom, wskazywać, jakie rezultaty byłyby pożądane”. Czyż te słowa nie brzmią bardzo aktualnie i czy nie można ich dedykować tym dzisiejszym politycznym decydentom, którzy są przekonani, że wiedzą lepiej od ludzi uniwersytetu, czego im potrzeba oraz co oni mogą i powinny robić?

W 1992 r. doktorat honoris causa został nadany przez Uniwersytet Łódzki prof. Leszkowi Kołakowskiemu, cenionemu (przynajmniej przez niektórych) filozofowi. Swojemu wystąpieniu nadał przewrotny tytuł Diabeł kłamie również, kiedy mówi prawdę. Pojawiły się w nim elementy rozliczenia z tą akademicką przeszłością, od której Kołakowski później się odcinał i którą krytykował w niejednej publikacji po 1960 r. (np. w tekście Główne nurty marksizmu). Można ją określić jako zauroczenie lub - jak wolą niektórzy ogłupienie marksistowską ideologią i filozofią. W każdym razie tak można rozumieć jego stwierdzenie, że „gdy ma się dwadzieścia czy dwadzieścia jeden lat, często jest się wszechwiedzącym; ja też byłem wszechwiedzący, dopiero potem stopniowo i powoli głupiałem. Jako ów wszechwiedzący zmiażdżyłem teorie Poincarégo (znakomitego francuskiego matematyka, fizyka i filozofa - uw. wł.), suchej nitki na nim nie zostawiłem. [...] Powinienem 
był pamiętać przykazanie Kotarbińskiego, który kazał nam odróżniać, jak mawiał, krytykę policyjną od opiekuńczej; krytyka policyjna to taka, gdzie się szuka tylko jakiejś dziury, żeby kogoś pogrążyć, a w opiekuńczej chodzi o to, żeby nawet z bardzo krytycznie ocenionych rzeczy coś dobrego wydobyć” (Kołakowski, 1994: 17 i n.). W tym wystąpieniu nie wspomina jednak o tym, że jako student Uniwersytetu Warszawskiego przyczynił się (razem z kilkoma innymi studentami) do pozbawienia prawa do wykładania na tej uczelni prof. Władysława Tatarkiewicza (wybitnego znawcę filozoficznych tradycji), a jako jej wykładowca w swoich wygłaszanych w roku akademickim 1954/1955 wykładach O filozofii średniowiecznej „,zmiażdżył” niejedną teologiczną znakomitość (Kołakowski, 1956). Przypomniał w nim natomiast, że „teologowie średniowieczni zwykli nazywać diabła ojcem kłamstwa, pater mendi, i mówili czasem, że diabeł kłamie również, kiedy mówi prawdę" (Kołakowski, 1956: 19). Nie byłby wszakże poważnym filozofem, gdyby do tego nie dodał jakiejś generalizacji - takiej chociażby jak ta, że „kiedy istnieje zorganizowany system kłamstwa, ma on również zawsze cząstkowe prawdy na swój użytek, ale tak spreparowane, żeby kłamstwu służyły i przez to jakby godności prawdy się wyzbyły”. Czy te słowa całkowicie straciły dzisiaj na aktualności? Można mieć co do tego istotne wątpliwości. Jak by jednak tego nie oceniać, wychodzi na to, że osiąganie i upowszechnianie prawdy jest sprawą zbyt poważną, aby można ją było pozostawić samym politykom i wspierającym ich ideologom.

Podobnie jest zresztą z kwestią zdobywania akademickiego obywatelstwa i określania zasad funkcjonowania w społeczności akademickiej. Mówił o tym prof. Twardowski w swoim wykładzie $O$ dostojeństwie Uniwersytetu. Przyznał w nim m.in., że po prawie pół wieku bycia członkiem uniwersyteckiej wspólnoty akademickiej, z dumą w sercu stał się obywatelem akademickim. Rzecz jasna, nie było to pierwsze lepsze obywatelstwo, lecz profesorskie, a takie uzyskują tylko stosunkowo nieliczni członkowie tej wspólnoty i - co nie mniej istotne - raczej nie można go otrzymać ani przez urodzenie, ani przez zasiedzenie, ani nawet przez oświadczenia takich „przybranych rodziców”, jakimi są różnego rodzaju opiekunowie i promotorzy osób ubiegających się o uzyskanie tego naukowego tytułu - każda z tych okoliczności może wszakże być pomocna przy jego zachowywaniu. Czy wiele zmieniło się pod tym względem na przestrzeni tego niemal tysiącletniego funkcjonowania europejskich uniwersytetów? Na to pytanie trudno udzielić jednoznacznej odpowiedzi.

Nie ulega jednak wątpliwości, że dzisiaj ta grupa akademickiej społeczności jest nie tylko liczniejsza niż w przeszłości, ale także znacznie bardziej 
zróżnicowana. Bez wątpienia jedni są bliżsi, inni zaś dalsi od spełniania tych wzorców doskonałości, o których mowa m.in. w wykładzie prof. Twardowskiego. Co więcej, pewnym członkom tej społeczności przychodzi to łatwiej, innym natomiast trudniej się do nich zbliżyć. Sporo tutaj zależy od ich zdolności oraz zaangażowania w wykonywanie zawodowych obowiązków, lecz również od tych okoliczności, na które ich wpływ jest ograniczony, takich m.in. jak przyzwolenie ich bliższego i dalszego otoczenia na sposób realizowania przez nich aspiracji oraz życiowych marzeń. Zbliżenie się do tych wzorców wymaga zwykle sporo czasu. Rzecz jasna, nie zawsze musi to być „prawie pół wieku”, jak w przypadku prof. Twardowskiego, lecz nie można tego zrobić (przynajmniej w polskich realiach akademickich) w kilka czy nawet kilkanaście lat pracy zawodowej. W związku z tym w naszym kraju profesorski tytuł uzyskuje się z reguły w stosunkowo późnym wieku, a wyjście zbyt wczesne przed szereg spotyka się niejednokrotnie z negatywną reakcją ze strony tych, którzy oceniają kwalifikacje takiego niecierpliwego kandydata do profesorskiego tytułu.

Należy dodać, że nie każdy z członków akademickiej wspólnoty chce i potrafi spełnić te wymagania, które są niezbędne, by uzyskać profesorski tytuł. Potwierdzeniem może tu być fakt, że na polskich uczelniach funkcjonuje znacznie liczniejsza grupa takich akademickich uczonych i wykładowców, którzy nie posiadają tego tytułu i zadowalają się (przynajmniej do pewnego czasu) stanowiskiem profesora uczelni. Nie jest przy tym tak, że są oni pozbawieni aspiracji i marzeń, które innych doprowadziły do profesorskiego tytułu, raczej brakuje im kwalifikacji tych ostatnich. Teoretycznie nic nie stoi na przeszkodzie, aby profesor uczelniany podwyższył swoje kwalifikacje i udokumentował je na tyle, aby pozbyć się tego przymiotnika przy swoim nazwisku i stanowisku. W praktyce wszakże niejednokrotnie bywa tak, że brakuje mu do tego nie tylko odpowiednich zdolności, ale także pracowitości. Dobrze, jeśli we właściwym momencie swojej zawodowej drogi potrafi to zrozumieć na tyle, aby nie podejmować prób osiągnięcia tego, co jest poza jego zasięgiem. Nieźle też, jeśli ma zarówno pewne zawodowe zdolności, jak i świadomość, że ich udoskonalenie będzie od niego wymagało dużo więcej pracy niż od bardziej uzdolnionych koleżanek i kolegów. Do tego wszakże potrzeba nie tylko samokrytycyzmu, ale również sporej pokory i cierpliwości. Nie jest o nie łatwo w sytuacji, gdy bardziej uzdolnieni i pracowici rówieśnicy już osiągnęli to, co jest przedmiotem marzeń tych osób. Poważny problem zaczyna się jednak dopiero wówczas, gdy takie przeciętnie uzdolnione i średnio pracowite osoby zamiast „wziąć się za siebie”, biorą się za tych, którym zazdroszczą ich zawodowego sukcesu, i nie tylko 
kwestionują ich uprawnienia do niego, ale także sposób jego uzyskania. Należy dodać, że w tej procedurze awansowej potrzeba też trochę szczęścia i życzliwości ze strony oceniających nasze osiągnięcia. Szczęściu i życzliwości w każdym przypadku trzeba pomóc, najlepiej poprzez takie udokumentowanie swoich osiągnięć, by ich wartość trudno było zakwestionować nawet najbardziej surowym opiniodawcom - a o to przecież nie jest niełatwo.

Najliczniejszą grupę uczelnianej społeczności stanowią jednak nie nauczyciele, lecz studenci. Uzyskanie przez nich akademickiego obywatelstwa jest z reguły łatwiejsze niż uzyskanie obywatelstwa profesorskiego. Nie znaczy to wszakże, że we wszystkich krajach jest o nie równie łatwo. Tam, gdzie studia są płatne, trzeba posiadać niejednokrotnie sporą kwotę na opłacenie czesnego, a i to może okazać się niewystarczające do uzyskania miejsca na prestiżowych i elitarnych uczelniach (takich jak Uniwersytet Cambridge czy Oxford), na których liczba studiujących jest mocno ograniczona. W Stanach Zjednoczonych można wprawdzie znaleźć wiele uczelni z niższym czesnym, lecz i ono bywa nieosiągalne dla młodzieży czy ich rodzin, a wtedy konieczne jest zaciągnięcie ciężkich do spłacenia kredytów. O tym, jak trudna jest to sytuacja, może świadczyć fakt, że jednym z pierwszych rozporządzeń obecnego prezydenta USA Joe Bidena było umorzenie części tych niespłacalnych kredytów.

W Polsce studia były i są, przynajmniej teoretycznie, bezpłatne (zapisano to w art. 70 Konstytucji RP). Inaczej jednak wyglądało to przed przełomem roku 1989, a inaczej wygląda dzisiaj. Przed tą datą w naszym kraju trzeba było pokonać na egzaminach wstępnych sporą liczbę konkurentów do uzyskania obywatelstwa akademickiego, gdyż liczba miejsc była stosunkowo niewielka, a ponadto brano pod uwagę tzw. pochodzenie społeczne (preferowane było robotnicze lub chłopskie). Po tej dacie nastąpiło tzw. umasowienie studiów wyższych w wyniku znacznie szerszego otwarcia dla kandydatów na studia bram uczelni publicznych oraz pojawienie się licznych uczelni niepublicznych (nazywanych potocznie prywatnymi). Oznaczało to nie tylko znaczne ułatwienia w dostaniu się na studia, ale także w niejednym przypadku znaczne obniżenie poziomu kształcenia. Dotyczy to przede wszystkim uczelni prywatnych. Płaciło się i płaci w nich wprawdzie za kształcenie, lecz ich niejednokrotnie wieloetatowej i zaawansowanej wiekowo kadrze trudno było i jest zagwarantować jego wysoki poziom, a ci, którzy podejmowali próby dokonania bardziej gruntownego „odsiewu” na egzaminach, ryzykowali utratę zatrudnienia, w ten bowiem sposób uszczuplali wpływy uczelni z czesnego. Niestety również na wielu uczelniach publicznych nastąpiło obniżenie wymagań stawianych akademickiemu kształceniu. 
Przyczyniło się to do pojawienia się na tych uczelniach takich studentów, których akademickie obywatelstwo było i jest w znacznej mierze formalne. Można ich spotkać na każdej uczelni w Polsce i na każdym kierunku studiów. Gdyby ich zapytać, w jakim celu podjęli studia, chociaż ani regularnie nie biorą udziału w zajęciach dydaktycznych, ani niespecjalnie angażują się w samokształcenie, zapewne podaliby jakiejś wyjaśnienie swojego postępowania. Odpowiedzi mogłyby też udzielić władze dziekańskie, które nierzadko tolerują zarówno przyjmowanie na studia każdego bez wyjątku, jak i pozorowanie studiowania - bo w końcu pieniądze „idą za studentem”, i idą za nim dopóty, dopóki znajduje się on na uczelnianej liście. Oczywiście taka polityka podtrzymywania studenckiego obywatelstwa może być przedmiotem krytyki, lecz zdarza się ona nawet na najlepszych polskich uczelniach. Osobną kwestią z nią związaną jest rzetelne ocenianie osiągnięć edukacyjnych studentów.

Problem rzetelnego oceniania dotyczy także osiągnięć naukowych pracowników uczelnianych. W środowisku akademickim mówi się, że powinny być one ocenianie „przez sobie równych” (peer review). Rzecz jednak w tym, że obecnie środowisko to, podobnie jak w przeszłości, jest ogromnie zróżnicowane zarówno pod względem posiadanych kwalifikacji, jak i tych aspiracji, które jednym pozwalają osiągnąć wysokie kwalifikacje, innych zaś stawiają w co najmniej dwuznacznej sytuacji, ponieważ wprawdzie chcieliby mieć taką pozycję w akademickiej hierarchii, jaką mają tamci, ale brakuje im do tego nie tylko ich zdolności, ale i pracowitości. Kłopot polega na tym, jak im to powiedzieć i przekonać, że ocena ich kwalifikacji i osiągnięć jest rzetelna oraz w miarę obiektywna. Nie ulega wątpliwości, że życie akademickie dostarcza wielu okazji do powiedzenia tego, lecz jednym akademikom to mówienie wychodzi lepiej, innym nieco gorzej, a jeszcze innym tak, że pojawia się pytanie: czy chodzi tutaj o rzetelną ocenę osiągnięć czy może o zademonstrowanie swojej wyższości nad osobą, która miała pecha, że trafiła na tak nieżyczliwego opiniodawcę. Krótko mówiąc, pojawia się tu problem nieobiektywnych i niejednokrotnie również niekompetentnych recenzentów, co dotyczy i procedur awansowych, i wydawniczych.

Sporo się w ostatnich latach w naszym kraju zmieniło, zarówno jeśli chodzi o zasady powoływania recenzentów, jak i rozliczania ich z wykonania obowiązków. Gdyby jednak trzeba byłoby odpowiedzieć na pytanie, czy obecne przepisy i sposoby ich egzekwowania doprowadziły do całkowitego wyeliminowania recenzentów niekompetentnych lub po prostu myślących głównie o tym, jak znaleźć jakieś niedoskonałości w osiągnięciach opiniowanych osób, to można by mieć poważne trudności. Zapewne ograniczyły 
one w jakiejś mierze taką środowiskową patologię, jaką było powoływanie recenzentów na tzw. zamówienie. W jednym przypadku oznaczało to oczekiwanie na recenzję zdecydowanie pozytywną, w innym na zdecydowanie negatywną. Wybór takich recenzentów nie był i nie jest specjalnie trudny, środowisko akademickie bowiem na ogół ma niezłe rozeznanie, u kogo daną recenzję można zamówić. Dzisiaj jest to o tyle trudniejsze, że przynajmniej w procedurach awansowych recenzenci są „z komputera”, jeśli można tak powiedzieć o ich losowaniu z grupy specjalistów w danej dyscyplinie. Taką listę ktoś jednak musi sporządzić. Co więcej, w niektórych dyscyplinach wysokiej klasy specjalistów jest tak niewielu, że do tej listy trzeba dopisać takich, których w zasadzie być tam nie powinno. Pół biedy, jeśli taki recenzent braki w swoich kwalifikacjach próbuje przysłaniać ogólnikowymi wątpliwościami. Gorzej, jeśli mimo tych braków formułuje jednoznacznie negatywne oceny.

Jak wygląda rzetelność oceniania w procedurach wydawniczych, mogli się przekonać ci uczeni, którzy ubiegali się o druk swoich monografii i artykułów w wydawnictwach stosujących procedury recenzyjne. Recenzowanie monografii i artykułów różni się nie tylko tym, że w pierwszym przypadku wymaga to zwykle więcej pracy niż w drugim, ale także tym, że recenzowanie monografii może być i z reguły jest płatne, artykułów zaś, przynajmniej formalnie, płatne być nie powinno. Powoduje to pewną różnicę w podejściu recenzentów, nie aż tak wielką jednak, aby można było powiedzieć, że recenzje monografii są z reguły znacznie bardziej wnikliwe i merytoryczne niż recenzje artykułów. Niejednokrotnie bowiem do wydawnictw trafiają recenzje monografii charakteryzujące się znaczną lapidarnością i ogólnikowością, a jeśli już pojawiają się w nich jakieś krytyczne uwagi, to dotyczą one kwestii drugorzędnych, lub wręcz marginalnych. W środowisku akademickim istnieje przekonanie, że znacznie łatwiej jest napisać recenzję z pozytywną niż z negatywną konkluzją, ponieważ ta druga wymaga gruntowniejszego uzasadnienia. Coś jest tu na rzeczy, nie zawsze wszakże, gdyż można spotkać się również z takimi recenzjami monografii, w których negatywna konkluzja nie ma dostatecznego uzasadnienia, i wygląda na to, że jej autor nie zadał sobie trudu uważnego zapoznania się z treścią opiniowanego tekstu. Być może tylko go przekartkował, albo nawet ograniczył się do zapoznania się wyłącznie ze spisem treści i tymi fragmentami, które go co nieco zainteresowały, a także z wykazem przywoływanych w bibliografii pozycji. Negatywną ocenę można wówczas w jakiejś mierze tłumaczyć tym, że nie znalazł w wykazie tych pozycji żadnej ze swoich publikacji. W końcu nie ma niczego złego w tym, że chce się być docenianym lub przynajmniej przywoływanym w publikacjach na tyle często, by wskaźniki wpływu były 
wysokie. Kwestią dyskusyjną jest jednak traktowanie ich jako, jeśli nawet nie jedynych, to przynajmniej najważniejszych wskaźników pozycji uczonego. Kwestią bezdyskusyjną jest natomiast to, że taka urażona ambicja recenzenta nie może stanowić wystarczającego usprawiedliwienia dla wystawienia negatywnej opinii o wartości naukowej recenzowanej monografii.

$\mathrm{Na}$ jeszcze większą skalę problem ten pojawia się w recenzowaniu artykułów naukowych. Teoretycznie gruntowne zapoznanie się z ich treścią i z zapleczem warsztatowym nie wymaga aż tak znaczącego nakładu pracy, aby nie chcieli się jej podjąć specjaliści w danej dyscyplinie lub dziedzinie oraz wykonać jej ze starannością niebudzącą zastrzeżeń i autorów, i redakcji czasopism, które zwróciły się z prośbą o napisanie recenzji. W praktyce wszakże bardzo różnie bywa z tą starannością. Oczywiście zdarzają się takie recenzje artykułów, które mają nie tylko zaznaczone w formularzu recenzyjnym odpowiednie części składowe recenzji (na „tak” lub „nie”), ale także wypełnione pole w rubryce „uzasadnienie oceny” lub „uwagi recenzenta”. Bywają jednak i takie, które mają zaznaczone wyłącznie to, co wymaga postawienia krzyżyka. Co więcej, również w samym tekście nie można znaleźć żadnego śladu pracy recenzenta. W takiej sytuacji pojawiają się uzasadnione wątpliwości, czy faktycznie zadał on sobie trud zapoznania się z opracowaniem. Trudno bowiem uwierzyć, że trafił na tekst pod każdym względem doskonały. Sporym problemem są też takie recenzje, których autorzy najwyraźniej albo mieli zły dzień, albo ujawnili jakieś żale do twórców opiniowanych tekstów. Wysyłane do recenzji prace powinny być i zwykle są anonimizowane. Jeśli jednak ich autorami są osoby o szeroko znanych zainteresowaniach i dokonaniach naukowych, to recenzenci bez większego trudu je rozpoznają - także ci, którzy napisanie negatywnej opinii traktują jako dobrą okazję do zrewanżowania się za swoje domniemane krzywdy. Niestety redaktorom czasopism mało kiedy znane są okoliczności powodujące pojawienie się tych „gorzkich żalów”, bo przecież gdyby je znali, zapewne przeciwstawiliby się takiemu procederowi. Takie rekompensowanie własnych krzywd różnie zresztą wygląda w recenzjach wydawniczych. Niekiedy recenzent zadaje sobie nawet spory trud, aby wykazać niekompetencję autora. Częściej zdobywa się jedynie na trud poszukania w tekście istotnych uchybień, a gdy ich nie znajduje, to traktuje marginalia (takie jak źle postawiony przecinek czy użycie terminu, którego nie rozumie) za wystarczającą podstawę do napisania, że w artykule występują błędy językowe, a jego autor nie potrafi poprawnie posługiwać się naukowym językiem.

Klamrą spinającą te sytuacje, które miały miejsce w opiniowaniu osiągnięć uczonych w pierwszych wiekach istnienia uniwersytetów, z sytuacją 
obecną może być przywołanie oceny osiągnięć naukowych z jednej strony francuskiego filozofa i teologa Piotra Abelarda (1079-1142), z drugiej natomiast dwóch uczonych z Uniwersytetu Jagiellońskiego, prof. Elżbiety Tabakowskiej oraz prof. Małgorzaty Majewskiej. Abelard był wykładowcą w paryskiej szkole katedralnej Notre Dame. Głoszone przez niego poglądy spotkały się z istotnymi zastrzeżeniami, np. ze strony takiego ówczesnego autorytetu teologicznego jak Bernard z Clairvaux (w uznaniu zasług dla Kościoła wyniesionego na ołtarze). Krytyczne opinie o poglądach Abelarda wyrażał on między innymi w listach do ówczesnych dostojników kościelnych. Przykładowo w liście do papieża Innocentego II pisał: „mamy tutaj we Francji nowego teologa, co się nim stał z wieloletniego mistrza filozofii. Od wczesnej młodości wydziwiał cuda w dialektyce, a obecnie dopuszcza się szaleństw w tłumaczeniu pism świętych. W omszałej przeszłości potępione i spleśniałe dogmaty wskrzesza na nowo do życia, a nadto wymyśla własne kacerstwa. [...] Gdy stara się rozumem wszystko wyjaśnić, podważa prawdy, co przerastają ludzką pojętność, owszem, takie głosi, co urągają zdrowemu rozsądkowi i są sprzeczne z wiarą" (Abelard, 1952: 161 i n.), a w liście do „magistra Iwona, kardynała Kurii Rzymskiej”, stwierdzał: „magister Piotr Abelard jest mnichem wyzutym z czci i wiary, opatem bez żadnej pieczy nad poddanymi; reguł nie strzeże, z klasztorem nic go nie wiąże. [...] A przecież czuje się bezpiecznym, ponieważ się chełpi, że w Kurii ma kardynałów i dygnitarzy spośród swoich uczniów, których obiera obrońcami starych i nowych zbereżeństw” (Abelard, 1952: 166 i n.). Trzeba dodać, że te opinie Bernarda z Clairvaux sprawiły, iż Abelard został pozbawiony prawa wykładania w paryskiej uczelni i zmuszony do szukania schronienia przed gniewem Rzymu najpierw w klasztorze Saint-Denis, a później w wybudowanej przez niego na pustkowiu chacie w pobliżu Nogent-sur-Seine w Szampanii (Clanchy, 1997).

Tak dramatycznie nie wyglądają losy wymienionych tutaj dwóch pań profesorek z UJ. Wygląda jednak na to, że czują się one, jeśli nawet nie zagrożone w swoim akademickim obywatelstwie (prof. Tabakowska jest już zresztą profesorem emerytowanym UJ), to co najmniej głęboko oburzone tym, co miało miejsce w trakcie recenzowania ich ,językoznawczej analizy haseł protestu Ogólnopolskiego Strajku Kobiet (OSK). Po dwóch pozytywnych recenzjach (jedna pochwalna, druga pełna zarzutów - niemal wyłącznie polityczno-ideologicznych i niemerytorycznych) artykuł przyjęło pismo językoznawcze, zapowiadając publikację. Ale przed paroma dniami dostałyśmy informację, że po namyśle zespół redakcyjny tekst odrzuca, bo P.T. Recenzent ocenił go ponownie i dopatrzył się w nim politycznego 
zaangażowania i apoteozy wulgaryzmów. Merytorycznych argumentów poza paroma drobiazgami - nie było, pełnego tekstu drugiej recenzji nam nie udostępniono. Tekstu recenzji nie pozwolono nam cytować, ale opisałyśmy sprawę, bo wydała się bulwersująca jako sygnał niebezpiecznych wydarzeń” (Tabakowska i Majewska, 2021: 1). Gdyby ktoś poprzestał jedynie na tych kilku wyjętych z szerszego kontekstu zdaniach, to zapewne mógłby powiedzieć, że jest to w gruncie rzeczy przypadek incydentalny i niewart przywołania w tak ważnej dla akademickiego życia sprawie, jaką jest rzetelne ocenianie osiągnięć naukowych. W dalszej części tej publikacji pojawiają się jednak takie uogólnienia, które skłaniają do poważnych dyskusji na ten temat. Jej autorki twierdzą bowiem, że „obecna sytuacja społeczno-polityczna (w Polsce) podsuwa ludziom nauki - humanistom i nie tylko - wiele tematów zasługujących na miano «wrażliwych»”, a „proces będący odwrotnością syndromu Sokala-Boghossiana jest niebezpieczny dla nauki, zwłaszcza w obecnej sytuacji, w której mówienie o emocjach łatwo jest pomylić z ich wyrażaniem”. Rzecz jasna, uczeni nie są wolni od przeżywania i wyrażania emocji. Jakaś ich doza jest dopuszczalna również w opiniowaniu osiągnięć naukowych. To nie one jednak powinny ostatecznie decydować o tym, że formułuje się pozytywne lub negatywne opinie. Jest to raczej oczywiste - lecz jakże trudne do praktycznego zrealizowania!

Świat akademicki staje obecnie przed wyzwaniami, które stanowią konsekwencję szybkich przemian społecznych i kulturowych, w tym procesów globalizacji. Jak wskazano w pierwszej części rozważań, niektóre z tych wyzwań nie są nowe, ponieważ sięgają czasów średniowiecznych. Inne natomiast wynikają wprost z dynamiki późnonowoczesnego społeczeństwa i nie mają swoich odpowiedników w przeszłości. Dotyczy to zwłaszcza sporów i debat, które w naturalny sposób przenikają w mury uniwersytetu z zewnątrz. Uniwersytety postrzegane są jako miejsce debat nie tylko naukowych, ale także światopoglądowych, by nie powiedzieć - ideologicznych. W demokratycznych społeczeństwach uznawane są za obszary wolności, przede wszystkim wolności słowa. Nie istnieje jednak powszechna zgoda co do tego, na czym wolność akademickiej debaty polega i gdzie znajdują się granice tej wolności.

Pierwszy problem polega na tym, że debata publiczna toczona na uniwersytecie nie ogranicza się do debaty naukowej. Ponieważ samo pojęcie debaty naukowej ulega zmianom związanym z kwestionowaniem przyjętych 
standardów naukowości, granica między naukowością i pseudonaukowością ulega rozmyciu, a bramy uniwersytetu zostają otwarte dla opinii niemającej wsparcia w badaniach naukowych. O ile świat akademicki ma narzędzia, za pomocą których może zmagać się z tym problemem, o tyle postępująca polityzacja i ideologizacja debaty publicznej, w tym debaty uniwersyteckiej, jest znacznie trudniejsza do opanowania. Nie ma niczego dziwnego w tym, że uczeni zabierają głos w społecznie istotnych kwestiach, będących przedmiotem ostrych sporów ideologicznych. Jeśli jednak debata uniwersytecka zostaje zdominowana przez uznawane za pewniki twierdzenia ideologiczne, których zwolennicy nie są zainteresowani wymianą racjonalnych argumentów, lecz wykorzystują powagę uniwersytetu do wygłaszania i forsowania swoich przekonań, format akademickiej dyskusji ulega zasadniczej zmianie: zinstytucjonalizowany sceptycyzm zostaje zastąpiony moralną pewnością. Na taki rozwój wydarzeń odwołujący się do tradycyjnych wartości uniwersytet pozwolić nie może, nawet jeśli głoszenie ideologicznych „prawd” odbywa się w imię wolności debaty. Pozwolić nie może dlatego, że właśnie w tym miejscu debata się kończy i zostaje zastąpiona nieznoszącym sprzeciwu artykułowaniem ideologicznych przekonań. Problem polega jednak na tym, że nawet w niektórych obszarach działalności naukowej granica między postawą naukową a ideologicznym zacietrzewieniem bywa trudna do przeprowadzenia.

Drugi problem wiąże się z granicami wolności słowa. Współczesny uniwersytet, instytucja, która wolność uprawiania nauki i wolność debaty akademickiej nie tylko stawia na wysokim miejscu, ale także szczyci się rzeczywistym praktykowaniem tej wolności, okazuje się instytucją, pod adresem której formułowane są żądania reglamentacji wolności akademickiej. Niekiedy żądania takie mogą być uzasadnione - zwłaszcza wówczas, gdy debata przestaje mieć cokolwiek wspólnego z debatą naukową lub gdy różne skrajne środowiska roszczą sobie prawo do szerzenia własnych ideologii, fałszywych informacji i teorii spiskowych pod ochronnym płaszczem uczelni (Tierney, 2021: 14). Wszak jednym z tradycyjnych zadań uniwersytetu jest dążenie do prawdy. Jednakże w wielu przypadkach postulaty ograniczania wolności akademickiej, a przede wszystkim praktyki wykluczania z debaty i zamykania ust oponentom, niejednokrotnie przy użyciu przemocy, muszą budzić poważne zaniepokojenie. Ostatnie wydarzenia w Stanach Zjednoczonych rodzą słuszne obawy o przyszłość wolności akademickiej. Mowa tutaj o serii protestów na amerykańskich kampusach, z których część stanowiła reakcję na rzekomo obraźliwe wypowiedzi lub zachowania nauczycieli akademickich oraz władz uczelni. Problem w tym, że wypowiedzi - w tym również takie, które wpisują się w normalną praktykę akademicką - uznawane 
były za akty przemocy wobec grup, które czuły się poszkodowane. Wielu nauczycieli przypłaciło swoje wypowiedzi utratą pracy - zostali zmuszeni do rezygnacji lub zwolnieni. Nie chodziło przy tym o takie słowa, które wpisują się w mowę nienawiści i w związku z tym mogą być penalizowane, ale o takie, które okazały się niezgodne z przyjętymi przez określone grupy studenckie definicjami poprawności politycznej. Greg Lukianoff i Jonathan Haidt (2018), autorzy analizujący wydarzenia na amerykańskich uczelniach, mówią wprost o „rozpieszczaniu amerykańskiego umysłu”, przez co rozumieją nadmierną i szkodliwą wrażliwość niektórych jednostek i grup na publicznie głoszone poglądy niezgodne z ich własnym systemem przekonań.

Nadwrażliwość, przesadna emocjonalność oraz nowy trybalizm skłaniają jednostki do uznania aktów wyrażania przekonań niezgodnych z ich systemem wartości za akty przemocy. A skoro osoba publiczna dopuszcza się przemocy, to - kontynuując ten tok rozumowania - powinna zostać zmarginalizowana, unieważniona lub przynajmniej uciszona. W ten oto sposób zjawisko określane mianem kultury unieważniania (cancel culture) wkracza na uniwersytety i prowadzi do istotnego ograniczenia wolności słowa. Amerykańska fundacja FIRE (The Foundation for Individual Rights in Education) podaje, że tylko w ciągu ostatnich pięciu lat ponad czterystu uczonych w USA było celem oskarżeń ze strony przeciwników ideologicznych, domagających się zwolnienia, zawieszenia, zdegradowania lub ocenzurowania wypowiedzi akademików.

Myliłby się jednak ten, kto wydarzenia w amerykańskich uniwersytetach składa na karb społecznej, politycznej i kulturowej specyfiki Stanów Zjednoczonych. Zjawisko to bowiem przybiera rozmiary globalne i nie omija europejskich, w tym polskich, uniwersytetów. Jest ono konsekwencją zmian kulturowych i społecznych, które obejmują również życie akademickie. $\mathrm{W}$ wyniku tych przemian to, co jeszcze w XX w. stanowiło rację istnienia uniwersytetu, ulega istotnym przeobrażeniom (Tierney, 2021: 14). Powodów do obaw o wolność akademicką jest znacznie więcej i dotyczą one uniwersytetów na różnych kontynentach (Hao, 2020).

Obrona wolności akademickiej napotyka trudne do przezwyciężenia przeszkody, ponieważ instytucjonalne działania, w szczególności zaś regulacje prawne mające na celu utrwalenie i wzmocnienie wolności debaty, mogą stanowić potencjalne zagrożenie dla autonomii uniwersytetu. Prawna ochrona wolności słowa może rozpościerać parasol ochronny nad jednostkami i grupami próbującymi wykorzystać przestrzeń akademickiej debaty do głoszenia silnie upolitycznionych i zideologizowanych przekonań, a także poglądów pseudonaukowych. 
I właśnie z obroną nauki przed zalewem pseudonaukowych opowieści, fałszywych informacji i teorii spiskowych wiąże się trzeci problem. Sprawa nie dotyczy obrony wyłącznie nauki, ale przede wszystkim społeczeństw, w których instytucje nauki działają i wobec których mają odpowiedzialne zadania. Nie jest bowiem tak, że pseudonauka proponuje jedynie alternatywne obrazy świata, które ścierają się na „rynku idei” z wytworami poznania naukowego. Pseudonauka i fałszywa informacja przenikają tkankę społeczną i bezpośrednio wpływają na zachowania jednostek i zbiorowości, przyczyniając się do rozpowszechnienia niekiedy katastrofalnych w skutkach działań. Pandemia COVID-19 ukazuje ten problem w całej okazałości, ponieważ towarzyszy jej pandemia dezinformacji, która głównie za pośrednictwem mediów społecznościowych oddziałuje nie tylko na umysły, ale także zachowania społeczne milionów ludzi na całym globie (Spitzberg, Tsou i Gawron, 2021). Zakres oddziaływania dezinformacji jest w tym przypadku na tyle duży, że może wpływać na rozwój właściwej pandemii. Współczesny problem z pseudonauką, dezinformacją i teoriami spiskowymi polega na tym, że nowe technologie, przede wszystkim media elektroniczne, pozwalają im zdobywać coraz szersze rzesze zwolenników.

Obrona przed pseudonauką staje wszakże przed problemem znacznie bardziej fundamentalnym, bo dotyczącym samej natury wiedzy naukowej i oddzielenia jej od wiedzy, która naukowa nie jest. Problem demarkacji, czyli rozgraniczenia nauki i pseudonauki, nie jest, rzecz jasna, problemem nowym, a jego początków szukać można już w czasach starożytnych (Drozdowicz, 2021: 19; Gordin, 2021: 1). Filozofia nauki, która szczególnie intensywnie zmagała się z tym problemem, zaproponowała w XX w. wiele rozwiązań, które jednak nie pozwalają precyzyjnie określić granic nauki. Krytykując falsyfikacjonistyczne kryterium demarkacji zaproponowane przez Karla Poppera, Larry Laudan określił problem demarkacji mianem pseudoproblemu (Laudan, 1983: 124). Argumentowano ponadto, że kryteria demarkacji zwykle nie mają zasięgu uniwersalnego, ponieważ tworzone są w celu wykluczenia określonych teorii z obszaru nauki (Gordin, 2021: 14). Kryterium demarkacji zaproponowane przez Poppera wymierzone było przede wszystkim przeciwko psychoanalizie.

Odpowiedzialność za rozpowszechnianie pseudonauki ponoszą nie tylko producenci pseudonaukowych koncepcji, ale także sami naukowcy, organizatorzy nauki tworzący instytucjonalne ramy jej działania, popularyzatorzy wiedzy naukowej oraz systemy edukacji powszechnej. Wydaje się prawdopodobne, że to właśnie komunikacja między nauką a społeczeństwem stanowi problem. Komunikacja ta ulega zerwaniu z chwilą gdy specjalizacja 
i zaawansowanie nauk czynią wiedzę naukową nieprzejrzystą, a przez to również nieprzydatną dla przeciętnego człowieka. Nie oznacza to wprawdzie, że edukacja i popularyzacja wiedzy mogą położyć kres pseudonauce, mogą jednak zbliżyć naukę do codziennego życia przeciętnego człowieka, co - jak wskazywał niegdyś Edmund Husserl (1999) - może przynajmniej w pewnym stopniu przezwyciężyć kryzys nauk.

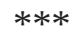

Oddawany do rąk czytelnika tom LII czasopisma „Człowiek i Społeczeństwo” składa się z kilkunastu artykułów, których przeważająca część dotyczy problemów życia akademickiego, w tym współczesnych badań naukowych.

Tom otwiera artykuł Zbigniewa Drozdowicza Akademickie batalie. Tradycje i współczesność, poświęcony dziejom zmagań społeczności akademickiej z zagrożeniami ze strony instytucji politycznych i kościelnych oraz ze strony koncepcji pseudonaukowych. Szczególna uwaga poświęcona została astrologii, przywoływanej jako jeden z przykładów. Autor podejmuje ponadto refleksję nad motywacjami i zewnętrznymi uwarunkowaniami rozwoju badań naukowych, ilustrując swój wywód przykładami uczonych i zespołów badawczych najwyższej klasy.

Tekst Jerzego Mariana Brzezińskiego Uniwersytet - nauki społeczne i humanistyczne - państwo podejmuje refleksję nad ideą uniwersytetu i podstawowymi zadaniami stojącymi współcześnie przed akademią. Do zadań tych należy: prowadzenie badań naukowych, kształcenie studentów i doktorantów, formacja studentów i doktorantów oraz popularyzacja wiedzy naukowej. Zaniedbanie realizacji tych zadań lub redukowanie roli uniwersytetu tylko do wybranych zadań niesie za sobą ryzyko poważnych kosztów związanych z pogorszeniem jakości badań oraz kształcenia. Autor wskazuje istotną rolę akademickiej kultury wspólnotowej, którą przeciwstawia wkraczającej do uniwersytetu kulturze korporacyjnej.

Marek Kwiek w artykule Globalny system akademicki i stratyfikujq̨ca rola badań naukowych wskazuje na obserwowane współcześnie trendy postępującego pionowego różnicowania profesji akademickiej w skali globalnej oraz koncentracji działalności badawczej w wyróżnionych ośrodkach. Autor w swoich rozważaniach wychodzi od czasów obecnych, ale koncentruje się przede wszystkim na nieodległej przyszłości, przewidując postępujące różnicowanie i ograniczenie tradycyjnego modelu łączącego kształcenie z badaniami tylko do elitarnych instytucji akademickich. 
Artykuł Andrzeja Wawrzynowicza Humanistyka akademicka w dobie postnauki. Kilka uwag o filozofii reform szkolnictwa wyższego w Polsce koncentruje się na kwestii statusu nauk humanistycznych, zwłaszcza zaś filozofii, w systemie nauki i szkolnictwa wyższego. Autor poddaje krytycznej refleksji zarówno zmiany zachodzące w skali globalnej, jak i wielokrotne reformy nauki oraz szkolnictwa wyższego w Polsce, wskazując na zagrożenia polegające na przesuwaniu się działalności naukowej ku sferze postnauki.

Kolejny tekst, autorstwa Stanisława Obirka, prezentuje jedną z koncepcji uniwersytetu. Jest to koncepcja zaproponowana przez kardynała Johna Henry'ego Newmana, który w uniwersytecie widział dostarczyciela wiedzy uniwersalnej, a nie praktycznie sprofilowanej. Zadaniem uniwersytetu, według tego myśliciela, jest wdrażanie do życia w społeczeństwie. Posługując się Newmanowską ideą uniwersytetu, autor krytycznie ocenia współczesne przemiany świata akademickiego, kierujące rozwój uniwersytetu na tory komercjalizacji i parametryzacji, prowadzące do degradacji uczelni jako instytucji oraz obniżenia statusu nauczyciela akademickiego.

Opracowanie autorstwa Zdzisława Puśleckiego Sztuczna inteligencja (AI), internet rzeczy (IoT) i sieć piq̨tej generacji (5G) w nowoczesnych badaniach naukowych poświęcony jest problematyce zastosowań najnowszych technologii, w tym ich wykorzystaniu w badaniach naukowych. Nowe metody zarządzania olbrzymimi bazami danych oraz narzędzia służące do analizowania danych otwierają nowe możliwości zarówno przed gospodarką, jak i przed światem badań naukowych. Autor podkreśla także rolę pandemii COVID-19 w przyśpieszeniu wdrażania nowych technologii.

Artykuł Sławomira Sztajera poświęcony jest problematyce roli intelektualisty publicznego, ze szczególnym uwzględnieniem religioznawcy. Autor koncentruje się nie tylko na funkcjach i zadaniach intelektualisty we współczesnym świecie, ale przede wszystkim zwraca uwagę na zagrożenia związane z publicznym zaangażowaniem, zwłaszcza na różnego rodzaju uwikłania ideologiczne religioznawców. Wskazuje też na doniosłość podejścia krytycznego oraz zadanie popularyzacji wiedzy religioznawczej.

Część tomu dotyczącą problematyki życia akademickiego zamyka tekst poświęcony Wzorom do naśladowania w budowaniu kultury rzetelności naukowej, autorstwa Agnieszki Dwojak-Matras, Katarzyny Kalinowskiej i Agnieszki Koterwas. Opracowanie jest rezultatem badań prowadzonych w ramach projektu „Path2Integrity - Rotatory role-playing and role-models to enhance the research integrity culture”. Autorki koncentrują się na promowaniu rzetelności badawczej poprzez zaangażowanie wzorów osobowych. 
Prezentowany tom zawiera ponadto dział „Forum dyskusyjne”, obejmujący zróżnicowane tematycznie artykuły, których autorami są: Tomasz Mróz, Przemysław Żebrok, Jerzy Bandel i Jowita Wycisk oraz Tomasz Herudziński. Całość zamyka napisana przez Marka Błaszczyka recenzja książki Psychologia kochania Piotra Olesińskiego.

\section{Literatura}

Abelard, P. (1952). Historia moich niedoli. Warszawa: Państwowy Instytut Wydawniczy. Clanchy, M. (1997). Abelard: A Medieval Life. Oxford: Blackwell.

Drozdowicz, Z. (2021). Między nauką i pseudonaukami. Od panpsychizmu do psychoanalizy. Nauka, 1, 19-37.

Gordin, M.D. (2021). On the Fringe: Where Science Meets Pseudoscience. Oxford: Oxford University Press.

Hao, Z. (2020). Academic Freedom Under Siege: What, Why, and What Is to Be Done. W: Z. Hao, P. Zabielskis (red.), Academic Freedom Under Siege (ss. 1-36). Cham, Switzerland: Spinger.

Husserl, E. (1999). Kryzys nauk europejskich i fenomenologia transcendentalna. Toruń: Wydawnictwo Rolewski.

Kołakowski, L. (1994). Diabeł kłamie również, kiedy mówi prawdę. W: Honoris Causa. Księga pamiq̨tkowa ku czci Leszka Kołakowskiego (ss. 15-23). Łódź: Wydawnictwo Łódzkie.

Kołakowski, L. (1956). Wykłady o filozofii średniowiecznej. Warszawa: Państwowe Wydawnictwo Naukowe.

Laudan, L. (1983). The Demise of the Demarcation Problem. W: R.S. Cohen, L. Laudan, Physics, Philosophy, and Psychoanalysis: Essays in Honor of Adolf Grünbaum (ss. 111-127). Dordrecht: D. Reidel Publishing Company.

Lukianoff, G., Haidt, J. (2018). The Coddling of the American Mind: How Good Intentions and Bad Ideas Are Setting Up a Generation for Failure. New York: Penguin Press.

Spitzberg, B.H., Tsou, M.-H., Gawron, M. (2021). Social Media Surveillance and (Dis) Misinformation in the COVID-19 Pandemic. W: H.D. O’Hair, M.J. O’Hair (red.), Communicating Science in Times of Crisis (ss. 262-301). Chichester: Wiley-Blackwell.

Twardowski, K. (2007). O dostojeństwie Uniwersytetu. Poznań: Zakład Graficzny UAM.

Tabakowska, E., Majewska, M. (2021). Poziom nauki i poziom komfortu. PAUza Akademicka, 570, 1-2.

Tierney, W.G. (2021). Higher Education for Democracy: The Role of the University in Civil Society. Albany, NY: State University of New York Press.

Woleński, J. (1985). Filozoficzna szkoła lwowsko-warszawska. Warszawa: Państwowe Wydawnictwo Naukowe.

Zbigniew Drozdowicz, Sławomir Sztajer

https://doi.org/10.14746/cis.2021.52.1 